\title{
Pituitary apoplexy in a patient with suspected metastatic bronchogenic carcinoma
}

\author{
Bik Ling Man, Yat Pang Fu
}

Department of Medicine and Geriatrics, Tuen Mun Hospital, Hong Kong, Hong Kong

\section{Correspondence to} Dr Bik Ling Man, beli_man@yahoo.com

Accepted 3 May 2014

CrossMark

To cite: Man BL, Fu YP. BMJ Case Rep Published online: [please include Day Month Year] doi:10.1136/ bcr-2013-202803

\section{DESCRIPTION}

We report the case of a 52-year-old man who was a chronic smoker and enjoyed good past health. He was admitted for progressive left-sided weakness and mild headache. He did not have any blurring
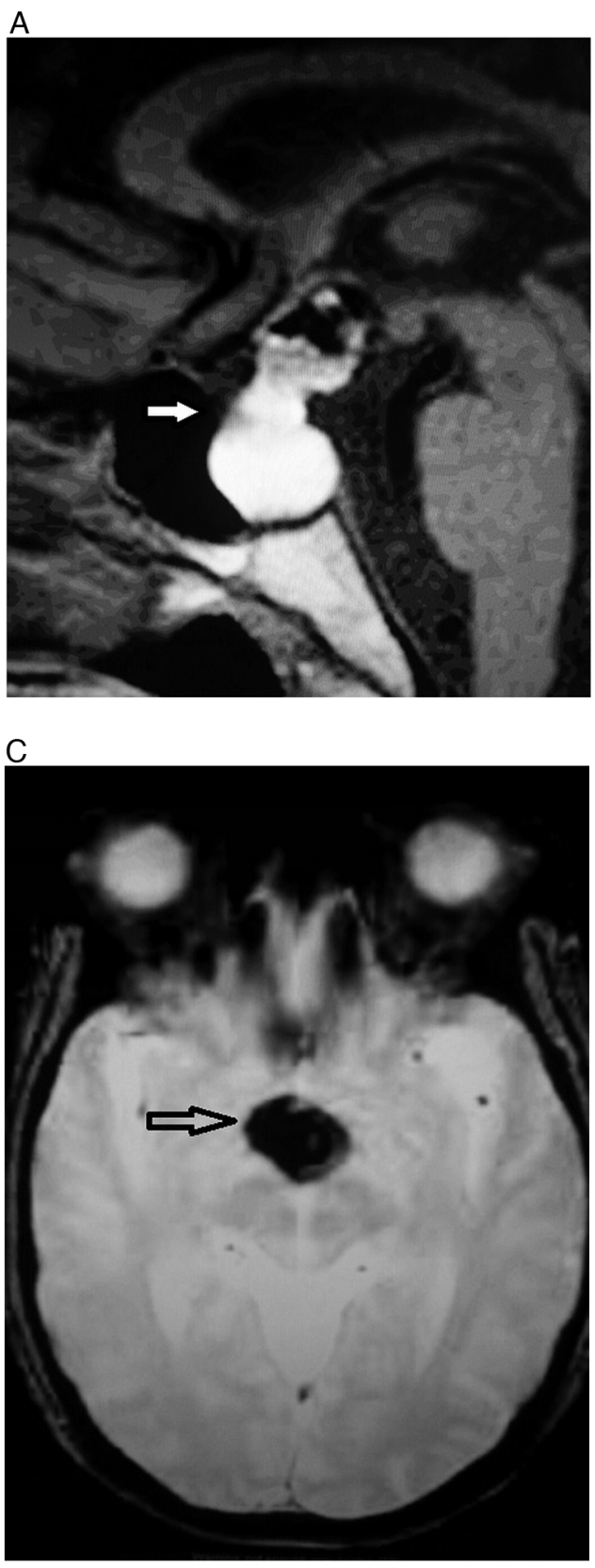

Figure 1 (A) MRI T1-weighted image sagittal view with gadolinium contrast showing the pituitary gland is diffusely enlarged with suprasellar extension (arrow). (B) MRI T1-weighted image coronal view with gadolinium contrast showing the pituitary gland is diffusely enlarged with suprasellar extension (arrow). (C) MRI Gradient echo image showing blooming artefact (arrow) suggesting haemorrhage and pituitary apoplexy. (D) MRI T1-weighted image with gadolinium contrast showing a small rim-enhancing nodule with vasogenic oedema over corticomedullary junction of right supratentorial region (arrow) which was likely brain metastasis.

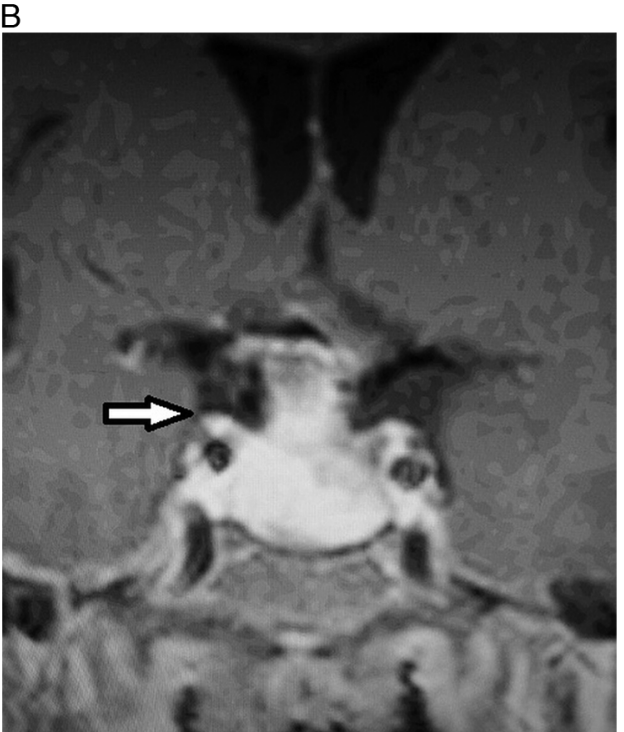

D

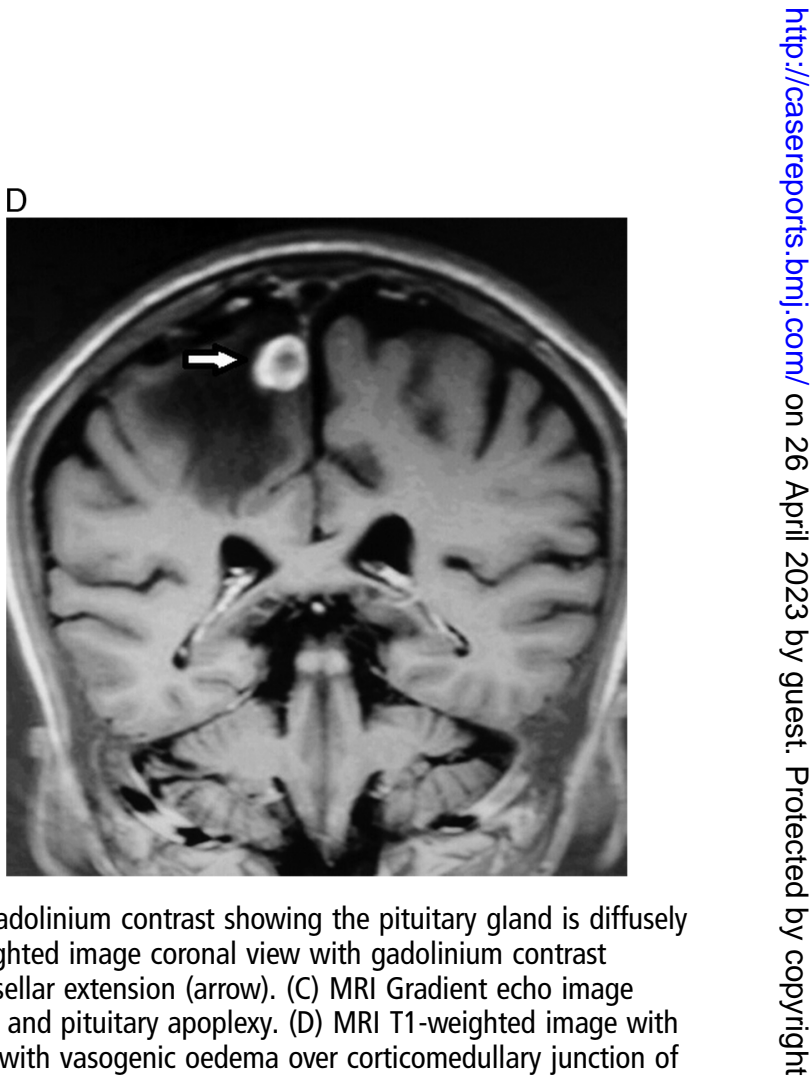

of vision, diplopia or change in mental status. $\mathrm{He}$ was alert and his blood pressure was normal on admission. Cranial nerve examination was normal and his visual field was full. The limb power was Medical Research Council grade 4/5 over his left 


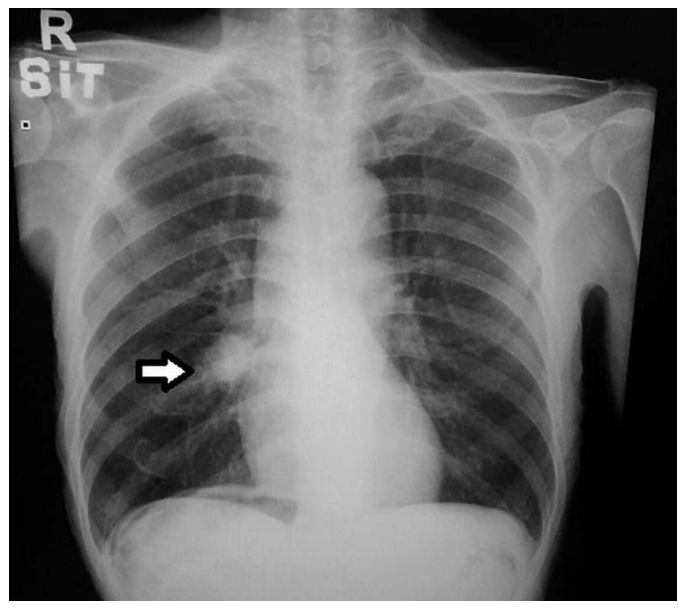

Figure 2 Chest X-ray showed a right infrahilar mass (arrow).

upper limb and 1/5 over left lower limb. The muscle tone was increased on the left side. The blood tests showed a normal complete blood picture, liver and renal functions. Pituitary hormonal profile revealed random cortisol $175 \mathrm{nmol} / \mathrm{L}$ (171-536), $\mathrm{FT}_{4} 9.9 \mathrm{pmol} / \mathrm{L}$ (9-19), thyroid-stimulating hormone $1.0 \mu / \mathrm{L}$ (0.35-4.94), prolactin $273 \mathrm{miu} / \mathrm{L}$ (86-324), follicle-stimulating hormone $0.3 \mathrm{iu} / \mathrm{L}(1.5-12.4)$, luteinising hormone $0.1 \mathrm{iu} / \mathrm{L}$ (1.78.6) and testosterone $0.09 \mathrm{nmol} / \mathrm{L}$ (6.68-25.7). MRI showed the pituitary gland was diffusely enlarged with suprasellar extension and blooming artefact suggesting pituitary apoplexy (figure 1A-C). Two small rim-enhancing nodules over corticomedullary junction were noted over supratentorial regions of bilateral cerebral hemispheres which were likely brain metastases (figure 1D). MRI of the whole spine showed no metastasis but there was carinal lymphadenopathy which was compatible with underlying bronchogenic carcinoma. Chest X-ray found a right infrahilar mass (figure 2) which was suggestive of bronchogenic carcinoma. The patient refused CT of the thorax, bronchoscopy and surgical intervention of pituitary apoplexy. He was given palliative care with dexamethasone and whole brain radiotherapy by the oncology department.

Bronchogenic carcinoma metastasised to the pituitary gland causing pituitary apoplexy is extremely rare. ${ }^{12}$ Since the patient refused surgical intervention, no biopsy was performed to confirm the diagnosis. The presence of supratentorial brain metastases together with suspicious right infrahilar opacity and carinal lymphadenopathy made metastatic bronchogenic carcinoma more likely than pituitary macroadenoma in this patient. Pituitary apoplexy is a life-threatening clinical syndrome caused by the rapid enlargement of a pituitary tumour due to haemorrhage and/or infarction. ${ }^{3}$ Although variable, it typically comprises of headache, visual deficits, ophthalmoplegia, altered consciousness and impaired pituitary function. An existing pituitary macroadenoma is usually present but it can occur with healthy glands in few isolated cases. ${ }^{4}$ About $14-22 \%$ of patients with radiologically identified pituitary haemorrhage have subclinical apoplexy with mild or no symptoms. ${ }^{3} 5$ Common precipitating factors include closed head trauma, blood pressure alterations, history of pituitary irradiation, cardiac surgery, anticoagulation, treatment with dopamine agonists, pituitary stimulation testing and pregnancy. ${ }^{6}$ Urgent neurosurgical decompression is needed in symptomatic patients. Improvement in visual field, visual acuity and diplopia is typically observed after therapy and some patients may require long-term hormonal therapy. $^{6}$

\section{Learning points}

- Pituitary apoplexy is a life-threatening clinical syndrome caused by the rapid enlargement of a pituitary tumour due to haemorrhage and/or infarction.

- About $14-22 \%$ of patients with radiologically identified pituitary haemorrhages have subclinical apoplexy with mild or no symptoms.

- Prompt neurosurgical intervention is needed in symptomatic patients.

\section{Competing interests None.}

Patient consent Obtained.

Provenance and peer review Not commissioned; externally peer reviewed.

\section{REFERENCES}

1 Chandra V, McDonald LW, Anderson RJ. Metastatic small cell carcinoma of the lung presenting as pituitary apoplexy and Cushing's syndrome. J Neurooncol 1984;2:59-66

2 Hanna FW, Williams OM, Davies JS, et al. Pituitary apoplexy following metastasis of bronchogenic adenocarcinoma to a prolactinoma. Clin Endocrinol (Oxf) 1999;51:377-81.

3 Lee JS, Park YS, Kwon JT, et al. Radiological apoplexy and its correlation with acute clinical presentation, angiogenesis and tumor microvascular density in pituitary adenomas. J Korean Neurosurg Soc 2011;50:281-7.

4 Nawar RN, AbdelMannan D, Selman WR, et al. Pituitary tumor apoplexy: a review. J Intensive Care Med 2008;23:75-90.

5 Findling JW, Tyrrell JB, Aron DC, et al. Silent pituitary apoplexy: subclinical infarction of an adrenocorticotropin-producing pituitary adenoma. J Clin Endocrinol Metab 1981;52:95-7.

6 Murad-Kejbou S, Eggenberger E. Pituitary apoplexy: evaluation, management, and prognosis. Curr Opin Ophthalmol 2009;20:456-61.

Copyright 2014 BMJ Publishing Group. All rights reserved. For permission to reuse any of this content visit http://group.bmj.com/group/rights-licensing/permissions.

BMJ Case Report Fellows may re-use this article for personal use and teaching without any further permission.

Become a Fellow of BMJ Case Reports today and you can:

- Submit as many cases as you like

- Enjoy fast sympathetic peer review and rapid publication of accepted articles

- Access all the published articles

- Re-use any of the published material for personal use and teaching without further permission

For information on Institutional Fellowships contact consortiasales@bmjgroup.com

Visit casereports.bmj.com for more articles like this and to become a Fellow 